Andrzej Pogtódek

Uniwersytet Kardynała Stefana Wyszyńskiego w Warszawie

\title{
INSTYTUCJA PREZYDENTA NADDNIESTRZAŃSKIEJ REPUBLIKI MOŁDAWSKIEJ
}

\section{Wprowadzenie}

Budowa państwowości w Naddniestrzu spowodowała także konieczność utworzenia instytucji głowy państwa ${ }^{1}$. Początkowo funkcję tę sprawował Przewodniczący Naddniestrzańskiej Mołdawskiej SRR. Pierwszym aktem prawnym regulującym status głowy państwa w Naddniestrzu była ustawa z dnia 5 marca $1991 \mathrm{r}$. „O statusie Przewodniczącego Naddniestrzańskiej Mołdawskiej Socjalistycznej Republiki Radzieckiej”. Urząd Prezydenta pojawił się wraz z przyjęciem Konstytucji Naddniestrzańskiej Republiki Mołdawskiej z dnia 2 września 1991 roku$^{2}$. Pierwsze wybory powszechne odbyły się w dniu 1 grudnia $1991 \mathrm{roku}^{3} .22$ grudnia $1991 \mathrm{r}$. urząd Przewodniczącego został przemianowany na urząd Prezydenta. Jego status nadal określała Konstytucja z 1991 roku i nie różni się on od statusu Przewodniczącego Naddniestrzańskiej Republiki Mołdawskiej. Prezydent, jako głowa państwa, był gwarantem przestrzegania Konstytucji i ustaw, praw i wolności obywateli, niezależnie od narodowości, przyjmował niezbędne środki w celu ochrony suwerenności republiki, jej integralności terytorialnej. Uprawnienia Prezydenta były określone w dziale 9 „Prezydent Naddniestrzańskiej Republiki Mołdawskiej” (art. 80-85). Konstytucja Naddniestrza z 1991 roku przewidywała także istnienie urzędu Wiceprezydenta. Wiceprezydent wybierany był wraz z Prezydentem. Urząd ten został

1 O rozwoju instytucji prezydenta patrz szerzej np.: Боту Бабирович Алимов, „Опыт зарубежных стран в вопросах взаимоотношений президента и правительства”, Вопросы современной юриспруденции 2015, Н 47; Марина Меджидовна Тхаркахо, „Зарождение и развитие института президентской власти в зарубежных странах", Вестник Адыгейского государственного университета. Серия 1: Регионоведение: философия, история, социология, юриспруденция, политология, культурология 2007, Н 1.

2 Конституция Приднестровской Молдавской Республики от 2 сентября 1991 г

$3 \quad$ W pierwszych wyborach prezydenckich przeprowadzonych 1 grudnia 1991 roku Prezydentem Naddniestrza został I. N. Smirnow, który otrzymał 65,5 procent głosów. 26 grudnia 1996 roku odbyły się wybory Prezydenta Naddniestrza, w których ponownie zwyciężył I. N. Smirnow zdobywając 71,94 procent głosów. W grudniu 2011 roku Prezydentem Naddniestrza został E.W. Szewczuk, wybrany w drugiej turze większością 73,88 procent głosów. 
utrzymany także w Konstytucji Naddniestrza z 1995 roku. Zlikwidowany został dopiero w wyniku zmiany Konstytucji z dnia 30 grudnia 2011 roku.

Na przełomie lat 1993-1995 trwały prace na nową Konstytucją Naddniestrza. Nowa Konstytucja Naddniestrzańskiej Republiki Mołdawskiej przyjęta została w referendum z dnia 24 grudnia $1995 \mathrm{roku}^{4}$. Wraz z nową Konstytucją status ustrojowy Prezydenta Naddniestrza został wzmocniony. W zgodzie z nową Konstytucją Naddniestrze stało się republiką o prezydenckiej formie rządów. Pod koniec 2011 roku wprowadzone zostały kolejne ważne zmiany w postaci wyodrębnienia rządu jako najwyższego organu władzy wykonawczej. Przedmiotem niniejszego artykułu jest przedstawienie pozycji ustrojowej Prezydenta Naddniestrza.

\section{Funkcje ustrojowe Prezydenta Naddniestrza}

Obowiązująca Konstytucja Naddniestrza z 1995 roku określa status Prezydenta w systemie organów władzy państwowej jako głowę państwa. Naddniestrze stanowi, co wprost wyraża Konstytucja, republikę prezydencką. W związku z przyjęciem zasady podziału władzy Prezydent działa niezależnie od władzy ustawodawczej i sądowniczej. Ze statusem głowy państwa powiązane zostały istotne funkcje ustrojowe nałożone na Prezydenta Naddniestrza. Prezydent Naddniestrza jest gwarantem Konstytucji i ustaw Naddniestrza, praw i wolności człowieka i obywatela, zapewnia dokładne wykonywanie Konstytucji i ustaw. W ustanowionym Konstytucją trybie podejmuje on działania w celu ochrony suwerenności republiki, jej niepodległości i integralności terytorialnej, zapewnia zgodne funkcjonowanie i wzajemne działanie wszystkich organów władzy państwowej. Prezydent, wykonując swoje ustrojowe funkcje powinien działać $\mathrm{w}$ granicach swoich konstytucyjnych uprawnień. Jednakże ze względu na model ustrojowy przyjęty w Naddniestrzu, może także podejmować działania, które nie są wyraźnie przewidziane w Konstytucji Naddniestrza. Funkcje ustrojowe głowy państwa stanowią więc, oprócz wskazania, w jakim duchu powinny być wykonywane, uprawnienia wyraźnie przyznane Prezydentowi przez Konstytucję, także samoistną podstawę do działania dla naddniestrzańskiej głowy państwa. Również przyznana Prezydentowi funkcja arbitra między organami władzy znacząco wzmacnia status ustrojowy. Jako arbiter Prezydent może wykorzystywać procedury pojednawcze dla rozstrzygania sporów między organami władzy wykonawczej i administracji Naddniestrza. W sytuacji nieosiągnięcia zgodnej decyzji może on skierować rozstrzygnięcie sporu do rozpatrzenia przez odpowiedni $\mathrm{sąd}^{5}$. Uprawnienia Prezydenta wymienione w Konstytucji Naddniestrza są prerogatywami osobistymi głowy państwa. W Naddniestrzu nie przyjęto bowiem instytucji

4 Конституция Приднестровской Молдавской Республики от 24 декабря 1995 г.

$5 \quad$ Art. 66 ust. 2 Konstytucji Naddniestrza. 
kontrasygnaty. Zgodnie z Konstytucją Naddniestrza ${ }^{6}$, Prezydent posiada nietykalność 7 Status Prezydenta powinna określić ustawa konstytucyjna. Akt ten jednakże do tej pory nie został uchwalony.

\section{Wybór Prezydenta Naddniestrza}

Okres kadencji Prezydenta wynosi 5 lat. Jedna i ta sama osoba nie może zajmować urzędu Prezydenta dłużej niż dwie następujące po sobie kadencje. Po czym po przerwie może ponownie ubiegać się o ten urząd. Prezydentem Naddniestrza może być wybrana osoba posiadająca od co najmniej 10 lat obywatelstwo Naddniestrzańskiej Republiki Mołdawskiej ${ }^{8}$, posiadająca prawo wyborcze, mająca ukończone 35 lat i stale zamieszkująca na terytorium Naddniestrza co najmniej 10 lat do dnia wyborów. Wyboru Prezydenta dokonują obywatele Naddniestrza na podstawie powszechnego, równego i bezpośredniego prawa wyborczego w głosowaniu tajnym ${ }^{9}$. Tryb przeprowadzenia wyborów Prezydenta określa Kodeks Wyborczy ${ }^{10}$. Prezydent wybierany jest w wyborach według systemu większości bezwzględnej. Ustawodawca określił, że wybory odbywają się w drugą niedzielę grudnia roku, w którym kończy się kadencja ${ }^{11}$. Ustawodawca ustalił, że rezultaty wyborów są ogłaszane przez Centralną Komisję Wyborczą nie później niż 5 dni od dnia wyborów. Wybranym zostaje kandydat, który otrzymał więcej niż połowę głosów wyborców biorących udział w wyborach, przy czym dla ważności wymagany jest udział ponad połowy osób znajdujących się w spisie wyborców ${ }^{12}$. Jeżeli żaden z kandydatów nie uzyskał wymaganej większości głosów, przeprowadza się drugą turę wyborów, w której nie obowiązuje wymóg uczestniczenia co najmniej 50 procent znajdujących się w spisie wyborców. Ponowne głosowanie odbywa się w ciągu 14 dni od dnia I tury głosowania. W II turze wyborów na Prezydenta zostaje wybrany ten kandydat,

$6 \quad$ Zob. Art. 59 Konstytucji Naddniestrza.

$7 \quad$ Wniosek o pozbawienie nietykalności osób zajmujących urząd Prezydenta i osób, które zakończyły wykonywanie swoich uprawnień, rozpatrywane są przez Radę Najwyższą na wniosek Prokuratora Naddniestrza, do którego dołącza się materiały, potwierdzające jego zasadność. Wniosek Prokuratora Naddniestrza i załączone do niego materiały przekazywane są w celu otrzymania konkluzji i przygotowania tego wniosku do rozpatrzenia przez Radę Najwyższą, do odpowiedzialnego komitetu (komisji), wyznaczony przez Przewodniczącego Rady Najwyższej. Na posiedzeniu Rady Najwyższej słowo dla wyłożenia istoty sprawy udziela się Prokuratorowi Naddniestrza. Po tym występuje przewodniczący odpowiedzialnego komitetu (komisji). Po sprawozdaniu przewodniczącego odpowiedzialnego komitetu (komisji) głosu udziela się osobie, w sprawie której rozpatruje się wniosek o pozbawienie nietykalności. Wymagana jest kwalifikowana większość od ustanowionej liczby deputowanych Rady Najwyższej (Art. 119 $19^{1}$ Regulaminu Rady Najwyższej).

8 Cenzus obywatelstwa wobec kandydata na urząd głowy państwa pojawił się w 2000 roku (21 июня) w wyniku zmiany Konstytucji.

9 Art. 60 Konstytucji Naddniestrza.

10 Закон от 9 августа 2000 г. „Избирательный кодекс Приднестровской Молдавской Республики”; Przed jego uchwaleniem tryb wyborów prezydenta określał Конституционный закон от 2 октября 1996 г. N 13-КЗ „О выборах президента Приднестровской Молдавской Республики".

11 W przypadku wyborów przedterminowych w drugą niedzielę miesiąca, po upływie trzech miesięcy od przedterminowego zakończenia kadencji. Przy tym nie są one przeprowadzane, jeżeli do zwykłych wyborów pozostało mniej niż 6 miesięcy (Art. 122 Kodeksu wyborczego). Art. 127 Kodeksu wyborczego. 
który otrzymał większą liczbę głosów niż kontrkandydat. Pod warunkiem, że otrzymał więcej głosów niż liczba tych, które padły przeciw obu kandydatom. Jeżeli obaj kandydaci otrzymają taką samą liczbę głosów, wówczas Prezydentem zostaje ten, który w I turze otrzymał więcej głosów. Jeżeli w II turze zrezygnuje kontrkandydat, i nie będzie innych kandydatów, to bierze w niej udział tylko jeden kandydat. Musi on jednak dla wyboru na Prezydenta otrzymać co najmniej 50 procent głosów wyborców uczestniczących w II turze ${ }^{13}$. W przypadku, gdy wybór nie został dokonany Rada Najwyższa zarządza powtórne wybory ${ }^{14}$. Obejmując urząd Prezydent składa narodowi przysięgę ${ }^{15}$. Składa ją nie później niż 30 dni po oficjalnym opublikowaniu rezultatów wyborów, w czasie uroczystości o podniosłym charakterze, w obecności deputowanych Rady Najwyższej, przedstawicieli organów wykonawczych i sądowych władzy państwowej. Prezydent przystępuje do wykonywania swoich obowiązków z chwilą złożenia przez niego przysięgi i kończy ich wykonywanie po upływie kadencji, z chwilą złożenia przysięgi przez nowo wybranego Prezydenta ${ }^{16}$.

Prezydent nie może zajmować żadnego innego odpłatnego urzędu, prowadzić gospodarczej i innej działalności, z wyłączeniem naukowej, pedagogicznej i innej twórczej działalności, wchodzić w skład organu kierowniczego lub organu nadzorczego organizacji komercyjnej, być deputowanym Rady Najwyższej i innych organów przedstawicielskich w Naddniestrzańskiej Republice Mołdawskiej. Prezydent zawiesza członkostwo w partiach politycznych i innych organizacjach społecznych, posiadających cele polityczne, na cały okres swojej kadencji ${ }^{17}$. Upływ kadencji Prezydenta pociąga za sobą zakończenie pełnomocnictw osób, bezpośrednio podległych Prezydentowi Naddniestrzańskiej Republiki Mołdawskiej. Nie dotyczy to przedterminowego zakończenia kadencji, wówczas następuje to bowiem po wybraniu nowej głowy państwa ${ }^{18}$.

Wykonywanie uprawnień Prezydenta kończy się przedterminowo w sytuacji dobrowolnej rezygnacji, trwałej niezdolności z przyczyn zdrowotnych wykonywania przynależnych mu pełnomocnictw, śmierci lub usunięcia z urzędu w trybie przewidzianym artykułem 75 Konstytucji Naddniestrza. We wszystkich sytuacjach, kiedy Prezydent nie jest w stanie wykonywać swoich obowiązków, czasowo wykonuje je Przewodniczący Rządu do ustania przyczyn, uniemożliwiających Prezydentowi

Art. 128 Kodeksu wyborczego.

Art. 131 ust. 1, 2 i 4 Kodeksu wyborczego; Powtórne wybory prezydenta odbywają się nie później niż cztery miesiące od dnia pierwszych wyborów albo nie później niż trzy miesiące od dnia uznania wyborów za nieważne. W powtórnych wyborach nie mogą wziąć udziału kandydaci, z powodu których wybory zostały uznane za nieważne (Ibidem).

Tekst przysięgi zgodnie z Konstytucją brzmi: „Ślubuję sprawując kompetencje Prezydenta Naddniestrzańskiej Republiki Mołdawskiej szanować i ochraniać prawa i wolności człowieka i obywatela, przestrzegać i bronić Konstytucję Naddniestrzańskiej Republiki Mołdawskiej i ustawy Naddniestrzańskiej Republiki Mołdawskiej, bronić suwerenności i niepodległości, bezpieczeństwa i integralności państwa, wiernie służyć narodowi Naddniestrzańskiej Republiki Mołdawskiej".

Art. 61 Konstytucji Naddniestrza.

Art. 64 Konstytucji Naddniestrza.

Art. 66 ust. 3 Konstytucji Naddniestrza. 
wykonywanie swoich obowiązków, lub do wybrania nowego Prezydenta. Przewodniczący Rządu, pełniąc obowiązki Prezydenta nie ma prawa rozwiązać Rady Najwyższej, a także wnosić projekt ustawy, przewidującej zmiany i (lub) uzupełnienia w Konstytucji Naddniestrza. W przypadku przedterminowego zakończenia kadencji Prezydenta, wybory prezydenckie przeprowadza się w drugą niedzielę miesiąca, następującego po trzecim miesiącu od daty przedterminowego zakończenia pełnomocnictw Prezydenta ${ }^{19}$.

\section{Prezydent Naddniestrza a Rada Najwyższa}

Prezydent zwołuje Radę Najwyższą na pierwsze posiedzenie nie później niż na trzydziesty dzień po oficjalnym opublikowaniu wyników wyborów, przy wyborze nie mniej niż dwóch trzecich ustanowionej liczby deputowanych Rady Najwyższej. Prezydent otwiera pierwsze posiedzenie Rady Najwyższej i powierza jego prowadzenie najstarszemu deputowanemu w celu wybrania Przewodniczącego Rady Najwyższej w ustanowionym trybie ${ }^{20}$. Prezydent może rozwiązać Radę Najwyższą w przypadku trzykrotnego odrzucenia kandydatury Przewodniczącego Rządu. Może, po ponownym wyrażeniu przez Radę Najwyższą w ciągu trzech miesięcy wotum nieufności Rządowi, rozwiązać Radę Najwyższą, jeżeli nie zdecyduje o odwołaniu Rządu. Na tej podstawie Rada Najwyższa nie może być rozwiązana w ciągu roku po jej wybraniu. Rada Najwyższa nie może być rozwiązana od momentu wysunięcia oskarżenia przeciw Prezydentowi, do przyjęcia odpowiedniej decyzji przez Radę Najwyższą. Rada Najwyższa nie może być rozwiązania w okresie obowiązywania na terytorium Naddniestrza stanu wojennego lub nadzwyczajnego, a także w ciągu sześciu miesięcy przed upływem kadencji Prezydenta ${ }^{21}$.

Prezydent Naddniestrza posiada prawo inicjatywy ustawodawczej. Prezydent ma prawo wprowadzić reżim konieczności ustawodawczej22 przy rozpatrywaniu najbardziej ważnych aktów ustawodawczych, wymagających rozpatrzenia i przyjęcia ich przez Radę Najwyższą w krótkim czasie ${ }^{23}$. Po uchwaleniu ustawy przez Radę Najwyższą Prezydent w ciągu 14 dni od otrzymania przyjętej przez Radę Najwyższą ustawy podpisuje ją i promulguje. Może jednak zwrócić ustawę do ponownego rozpatrzenia przez Radę Najwyższą w całości lub w częśsi ${ }^{24}$. W takim przypadku Rada

19 Art. 62 Konstytucji Naddniestrza.

20 Art. 67 ust. 3 Konstytucji Naddniestrza.

21 Art. 76 Konstytucji Naddniestrza.

22 Przy wprowadzeniu tego reżimu Rada Najwyższa obowiązana jest zawiesić rozpatrywanie innych projektów ustaw, oprócz wniesionego w reżimie konieczności ustawodawczej. Projekt ustawy, wniesiony przez Prezydenta w reżimie konieczności ustawodawczej, musi być rozpatrzony i przyjęty lub odrzucony w ustanowionym trybie na posiedzeniach sesji Rady Najwyższej w uzgodnionym z Prezydentem czasie.

23 Art. 72 Konstytucji Naddniestrza.

24 W przypadku ustawy finansowej Prezydent ma prawo odrzucić i skierować do powtórnego rozpatrzenia poszczególne jej artykuły lub sugerować zmniejszenie środków, zatwierdzonych przez Radę Najwyższą. Odrzucenie i skierowanie do powtórnego rozpatrzenia niektórych artykułów, postanowień ustawy finansowej nie jest przeszkodą dla jego podpisania i wejścia w życie. 
Najwyższa może ponownie ją przyjąć, większością dwóch trzecich głosów ustanowionej Konstytucją liczby deputowanych Rady Najwyższej. Ponownie przyjęta ustawa lub jej część jest podpisywana przez Prezydenta w ciągu 7 dni i promulgowana. Prezydent nie może odrzucić i skierować do powtórnego rozpatrzenia przyjęte przez Radę Najwyższą ustawy konstytucyjne, uzupełnienia i zmiany w Konstytucji, a obowiązany jest je podpisać i promulgować. Prezydent także nie ma prawa odrzucić decyzji o przedterminowym rozwiązaniu lokalnych Rad deputowanych ludowych ${ }^{25}$.

Prezydent zwraca się z przesłaniem do narodu Naddniestrzańskiej Republiki Mołdawskiej, Rady Najwyższej i periodycznie informuje o najbardziej ważnych sprawach polityki wewnętrznej i zagranicznej republiki, przedstawia Radzie Najwyższej coroczne sprawozdania o sytuacji w republice i zgłasza w celu rozpatrzenia takie środki, które uznaje za niezbędne i pożyteczne ${ }^{26}$.

Oprócz tego Prezydent przedstawia Radzie Najwyższej szereg kandydatów na różne urzędy państwowe, przykładowo kandydaturę na urząd Przewodniczącego Banku Centralnego. Przedstawia także Radzie Najwyższej wniosek o jego odwołanie z urzędu. Ważne jest także, że Prezydent posiada prawo czasowego powoływania na wszystkie wakaty, powstałe w przerwie między sesjami Rady Najwyższej, na urzędach państwowych, powołania, na które dokonuje Rada Najwyższa na wniosek Prezydenta, do obsadzenia tych urzędów w ustanowionym trybie na najbliższej sesji ${ }^{27}$.

\section{Prezydent Naddniestrza a władza wykonawcza}

Do 2012 roku władza wykonawcza w Naddniestrzu sprawowana była przez Prezydenta $^{28}$. W wyniku zmiany Konstytucji pojawił się Rząd ${ }^{29}$ jako odrębny od Prezydenta najwyższy organ władzy wykonawczej. Ustawa zasadnicza przewidziała jednak liczne uprawnienia głowy państwa wobec Rządu. Po pierwsze, Prezydent powołuje, za zgodą Rady Najwyższej, Przewodniczącego Rządu ${ }^{30}$, który przedsta-

25 Art. 73 Konstytucji Naddniestrza.

26 Art. 63 ust. 5 Konstytucji Naddniestrza.

27 Art. 66 ust. 1 lit. d, f i m Konstytucji Naddniestrza.

28 Zmiany zostały wprowadzone w 2011 roku, zob.: Конституционный закон Приднестровской Молдавской Республики от 4 июля 2011 года № 94-КЗИД-V «О внесении изменений и дополнений в Конституцию Приднестровской Молдавской Республики» (САЗ 11-27).

29 O Rządzie Naddniestrza zob.: Конституционный закон от 9 ноября 2011 г „О Правительстве Приднестровской Молдавской Республики".

30 Art. 76-2 Konstytucji Naddniestrza; Wniosek o kandydaturze Przewodniczącego Rządu wnosi się nie później niż w ciągu dwóch tygodni po objęciu urzędu przez nowo wybranego Prezydenta lub po ustąpieniu Rządu lub w ciągu dwóch tygodni od dnia odrzucenia kandydatury przez Radę Najwyższą. Rada Najwyższa rozpatruje przedstawioną przez Prezydenta kandydaturę Przewodniczącego Rządu w ciągu tygodnia od dnia wniesienia wniosku z tą kandydaturą. Prezydent ma prawo przedstawić jedną i tę samą kandydaturę na urząd Przewodniczącego Rządu nie więcej niż dwa razy. Po trzykrotnym odrzuceniu przedstawionych kandydatur Przewodniczącego Rządu przez Radę Najwyższą Prezydent powołuje Przewodniczącego Rządu, rozwiązuje Radę Najwyższą, z wyłączeniem sytuacji, przewidzianych Art. 76 ust. 3 i 4 Konstytucji Naddniestrza (Ibidem). 
wia Prezydentowi kandydatury na urzędy zastępców Przewodniczącego Rządu, ministrów, kierowników administracji państwowej miast, rejonów ${ }^{31}$. Na jego wniosek Prezydent odwołuje także wymienione osoby ${ }^{32}$. Rząd może podać się do dymisji, którą przyjmuje lub odrzuca Prezydent. Prezydent może podjąć decyzję o dymisji Rządu. Rada Najwyższa może wyrazić wotum nieufność Rządowi. Postanowienie o wotum nieufności Rządowi przyjmuje się dwiema trzecimi głosów ustanowionej Konstytucją liczby deputowanych Rady Najwyższej. Po wyrażeniu przez Radę Najwyższą wotum nieufności Rządowi, Prezydent ma prawo ogłosić dymisję Rządu lub nie zgodzić się z decyzją Rady Najwyższej. W sytuacji, jeśli Rada Najwyższa w ciągu trzech miesięcy powtórnie wyrazi wotum nieufności Rządowi, Prezydent ogłasza dymisję Rządu lub rozwiązuje Radę Najwyższą. W sytuacji dymisji lub złożenia pełnomocnictw Rząd, na podstawie dekretu Prezydenta, kontynuuje działanie do utworzenia nowego Rządu ${ }^{33}$. Rząd jest także obowiązany do złożenia rezygnacji przed nowo wybranym Prezydentem ${ }^{34}$. Odnośnie bieżącej działalności Rządu to Prezydent określa podstawowe kierunki polityki wewnętrznej Naddniestrza, ma także prawo przewodniczyć posiedzeniom Rządu ${ }^{35}$. Może także uchylać postanowienia i rozporządzenia Rządu w przypadku ich niezgodności z Konstytucją, ustawami i dekretami Prezydenta ${ }^{36}$. Prezydent zatwierdza także nagrody państwowe, ustanawia honorowe i specjalne tytuły, wręcza nagrody państwowe, nadaje tytuły honorowe Naddniestrza, wyższe wojskowe i specjalne tytuły, wyższe klasy kwalifikacyjne i rangi klasowe ${ }^{37}$.

\section{Uprawnienia Prezydenta Naddniestrza w stosunku do władzy sądowniczej}

Konstytucja Naddniestrza określa Prezydenta jako gwaranta niezawisłości władzy sądowniczej ${ }^{38}$. Poza tak ogólnie określoną funkcją Prezydent powołuje dwóch sędziów Sądu Konstytucyjnego oraz sędziów innych sądów. Przedstawia Radzie Najwyższej kandydatury na urzędy przewodniczących sądów: Konstytucyjnego, Najwyższego, Arbitrażowego, a także kandydaturę na Prokuratora Naddniestrzańskiej Republiki Mołdawskiej. Wnosi do Rady Najwyższej wniosek o odwołanie $\mathrm{z}$ urzędu Prokuratora Naddniestrza ${ }^{39}$. Prezydent posiada także prawo łaski ${ }^{40}$.

Art. 76-3 ust. 2 Konstytucji Naddniestrza.

Art. 66 ust. 1 lit. g Konstytucji Naddniestrza.

Art. 76-8 Konstytucji Naddniestrza.

Art. 76-7 Konstytucji Naddniestrza.

Art. 66 ust. 1 lit. b Konstytucji Naddniestrza.

Art. 76-6 ust. 3 Konstytucji Naddniestrza.

Art. 63 ust. 4 Konstytucji Naddniestrza.

Art. 80 ust. 4 zd. 1 Konstytucji Naddniestrza.

Art. 66 ust. 1 lit. f. Konstytucji Naddniestrza.

Art. 63 ust. 2 Konstytucji Naddniestrza. 


\section{Uprawnienia Prezydenta Naddniestrza w sferze obronności i bezpieczeństwa państwa}

Prezydent Naddniestrzańskiej Republiki Mołdawskiej jest Głównodowodzącym Sił Zbrojnych Naddniestrzańskiej Republiki Mołdawskiej. Jako taki m.in. powołuje i odwołuje najwyższe dowództwo Sił Zbrojnych Naddniestrzańskiej Republiki Mołdawskiej oraz zatwierdza doktrynę wojenną Naddniestrza. W sytuacji agresji przeciw Naddniestrzańskiej Republice Mołdawskiej lub bezpośredniej groźby agresji, Prezydent Naddniestrzańskiej Republiki Mołdawskiej wprowadza na terytorium Naddniestrzańskiej Republiki Mołdawskiej stan wojenny i niezwłocznie powiadamia o tym Radę Najwyższą. Prezydent występuje także do Rady Najwyższej o podjęcie decyzji o użyciu Sił Zbrojnych Naddniestrza poza granicami republiki. Prezydent Naddniestrzańskiej Republiki Mołdawskiej w okolicznościach i w trybie, przewidzianym ustawą konstytucyjną $\mathrm{O}$ szczególnych reżimach prawnych ${ }^{41}$, wprowadza na terytorium Naddniestrzańskiej Republiki Mołdawskiej lub w niektórych jej miejscowościach stan nadzwyczajny i niezwłocznie powiadamia o tym Radę Najwyższą Naddniestrzańskiej Republiki Mołdawskiej ${ }^{42}$.

\section{Uprawnienia Prezydenta Naddniestrza w sferze stosunków międzynarodowych}

Prezydent sprawuje kierownictwo polityki zagranicznej Naddniestrzańskiej Republiki Mołdawskiej i określa jej podstawowe kierunki. Jako głowa państwa reprezentuje Naddniestrze w stosunkach międzynarodowych. Prowadzi negocjacje i podpisuje umowy międzynarodowe Naddniestrzańskiej Republiki Mołdawskiej, podpisuje dokumenty ratyfikacyjne, przyjmuje listy uwierzytelniające i odwoławcze przedstawicieli dyplomatycznych. Powołuje i odwołuje, po konsultacji z odpowiednimi komitetami i komisjami Rady Najwyższej, przedstawicieli dyplomatycznych Naddniestrza w państwach obcych i organizacjach międzynarodowych. Prezydent rozstrzyga także sprawy obywatelstwa ${ }^{43}$ i przyznaje azyl polityczny ${ }^{44}$.

\section{Odpowiedzialność konstytucyjna Prezydenta Naddniestrza}

Prezydent może być usunięty z urzędu przez Radę Najwyższą tylko na podstawie wysuniętego przez nią oskarżenia o zdradę państwa lub popełnienie innego,

\footnotetext{
41 Конституционный закон Приднестровской Молдавской Республики от 10 июля 2002 г. „Об особых правовых режимах".

42 Art. 63 ust. 1 , Art. 66 ust. 1 lit. m) i Art. 94 ust. 1 zd. 2 Konstytucji Naddniestrza.

43 O obywatelstwie Naddniestrza zob.: Конституционный закон от 10 июля 2002 г. „О гражданстве Приднестровской Молдавской Республики".

44 Art. 63 ust. 3 Konstytucji Naddniestrza; Szczegółowo uprawnienia Prezydenta w tej sferze określa: Закон от 31 октября 2006 г. «О международных договорах» і Закон от 14 июля 2004 г. «О дипломатической службе Приднестровской Молдавской Республики».
} 
szczególnie poważnego przestępstwa (przestępstw) potwierdzonego opinią Sądu Najwyższego o obecności w działania Prezydenta oznak przestępstwa i opinią Sądu Konstytucyjnego o zachowaniu ustanowionego trybu wysunięcia oskarżenia. Inicjatywę wysunięcia oskarżenia i usunięcia z urzędu Prezydenta rozpatruje się na wniosek nie mniej niż jednej trzeciej ustanowionej Konstytucją liczby deputowanych Rady Najwyższej, i przy posiadaniu opinii komisji specjalnej, utworzonej przez Radę Najwyższą. Wniosek o usunięciu z urzędu Prezydenta musi być rozpatrzony przez Radę Najwyższą nie później niż w terminie dwumiesięcznym od wysunięcia oskarżenia. Jeśli w tym czasie decyzja Rady Najwyższej nie będzie przyjęta, oskarżenie uznaje się za odrzucone. Decyzja o usunięciu z urzędu Prezydenta przyjmowana jest nie mniej niż dwiema trzecimi głosów ustanowionej Konstytucją liczby deputowanych Rady Najwyższej. Taka decyzja oznacza usunięcie z zajmowanego urzędu ${ }^{45}$.

\section{Akty urzędowe Prezydenta}

Prezydent Naddniestrzańskiej Republiki Mołdawskiej wydaje dekrety i rozporządzenia. Posiadają one moc powszechnie obowiązującą na obszarze Naddniestrza. Jako akty podustawowe muszą być one zgodne z Konstytucją i ustawami Naddniestrza ${ }^{46}$.

Prezydent Naddniestrza tworzy Administrację Prezydenta ${ }^{47}$. Stanowi ona organ państwowy, który pomaga Prezydentowi w wykonywaniu jego zadań, a także sprawuje kontrolę nad wykonywaniem decyzji Prezydenta Naddniestrza ${ }^{48}$. Prezydent powołuje i odwołuje z urzędu pełnomocnych przedstawicieli Prezydenta ${ }^{49}$, którzy reprezentują interesy Prezydenta w organach władzy państwowej. Spośród innych organów wyróżnić należy Radę Bezpieczeństwa Naddniestrza, będącą organem doradczym Prezydenta w sprawach bezpieczeństwa i obronności państwa ${ }^{50}$; Komisję

Art. 75 Konstytucji Naddniestrza; Regulacja ta jest rozwijana w art.111-115 Regulaminu Rady Najwyższej; Porównawczo o odpowiedzialności konstytucyjnej głowy państwa patrz szerzej: Дзыбова Саида Гиссовна, „Инстит ут конституционно-правовой ответственности в современных правовых системах: сравнительно-правовой анализ", Вестник Адыгейского государственного университета. Серия 1: Регионоведение: философия, история, социология, юриспруденция, политология, культурология 2008, Н 8.

46 Art. 65 Konstytucji Naddniestrza.

$47 \quad$ Art. 66 ust. 1 lit. I) Konstytucji Naddniestrza.

48 Szczegółowo odnośnie statusu Administracji Prezydenta zob.: Указ Президента ПМР от 20 февраля 2012 г. №115 «Об утверждении Положения об Администрации Президента Приднестровской Молдавской Республики», http://president.gospmr.ru/ru/news/ukaz-prezidenta-pmr-no115-ob-utverzhdenii-polozheniya-ob -administracii-prezidenta (data dostępu: 15.09.2015 r.).

49 Art. 66 ust. 1 lit. k) Konstytucji Naddniestrza.

50 Szczegółowo odnośnie statusu Rady Bezpieczeństwa zob.: Указ Президента ПМР от 4 июня 2015 г № 226 «Об утверждении Положения о Совете безопасности Приднестровской Молдавской Республики», http:// president.gospmr.ru/ru/news/ukaz-prezidenta-pmr-no-226-ob-utverzhdenii-polozheniya-o-sovete-bezopasnosti -pridnestrovskoy (data dostępu: 15.09.2015 r.). 
ds. Prawa Łaski ${ }^{51}$; Komisję ds. Obywatelstwa ${ }^{52}$; Radę Konsultacyjną ds. Międzynarodowych $^{53}$; Najwyższą Radę Konsultacyjna ds. Nauki i Techniki ${ }^{54}$, Radę Społeczną - Radę Starszych ${ }^{55}$, Izbę Społeczną ${ }^{56}$, Komisję ds. Nagród Państwowych ${ }^{57}$; Radę Koordynacyjną ds. walki z przestępczością i korupcją ${ }^{58}$, a także inne ciała doradcze.

\section{Podsumowanie}

Pojawienie się urzędu Prezydenta w Naddniestrzu związane było z budową państwowości na lewym brzegu ówczesnej Mołdawskiej SRR. To, a także wciąż nieuregulowany status prawno-międzynarodowy Naddniestrzańskiej Republiki Mołdawskiej wywierał znaczący wpływ na rozwój jej instytucji państwowych. Podobnie jak w większości innych państw na obszarze poradzieckim, ustrój Naddniestrza przeszedł ewolucję od ustroju parlamentarnego u początku państwowości po przyjęcie ustroju rządów prezydenckich. Uregulowania tymczasowe obowiązujące w latach 1990-1991 przewidywały de facto ustrój parlamentarny, co wynikało z formalnego kształtu radzieckiego ustroju państwowego. Także przyjęta w 1991 roku Konstytucja z dnia 2 września 1991 roku utrzymała ustrój parlamentarny w którym Prezydent Naddniestrza odgrywał, w myśl postanowień ustawy zasadniczej, niewielką rolę, choć stał na czele rządu. Praktyka polityczna Naddniestrza odbiegała jednak od litery prawa. Przyjęcie w 1995 roku nowej Konstytucji, a wraz z nią

51 Указ Президента Приднестровской Молдавской Республики от 5 марта 2012 года № 152 «Об образовании при Президенте Приднестровской Молдавской Республики Комиссии по вопросам помилования», http:// president.gospmr.ru/en/news/ukaz-prezidenta-pmr-no152-ob-obrazovanii-pri-prezidente-pridnestrovskoy-moldavskoy-respubliki (data dostępu: 15.09.2015 r.).

52 Указ Президента ПМР от 1 марта 2012 г. № 143 «Об утверждении Положения о Комиссии по вопросам гражданства при Президенте Приднестровской Молдавской Республики и ее состава», http://president.gospmr.ru/ru/news/ukaz-prezidenta-pmr-no143-ob-utverzhdenii-polozheniya-o-komissii-po-voprosam-grazhdanstva-pri (data dostęp: 15.09.2015 r.).

53 Указ Президента ПМР от 17 февраля 2012 г. №107 «О Консультативном Совете при Президенте Приднестровской Молдавской Республики по международным делам », http://president.gospmr.ru/ru/news/ ukaz-prezidenta-pmr-no107-o-konsultativnom-sovete-pri-prezidente-pridnestrovskoy-moldavskoy (data dostępu: 15.09.2015 r.).

54 Указ Президента ПМР от 25 июня 2013 г. №293 «О создании Высшего консультативного совета по науке и технике при Президенте Приднестровской Молдавской Республики», http://president.gospmr.ru/ru/news/ ukaz-prezidenta-pmr-no293-o-sozdanii-vysshego-konsultativnogo-soveta-po-nauke-i-tehnike-pri (data dostępu: 15.09.2015 r.).

55 Указ Президента ПМР от 5 марта 2013 г. №86 «Об образовании при Президенте Приднестровской Молдавской Республики Общественного совета - Совета старейшин», http://president.gospmr.ru/ru/news/ ukaz-prezidenta-pmr-no86-ob-obrazovanii-pri-prezidente-pridnestrovskoy-moldavskoy-respubliki (data dostępu: 15.09.2015 r.).

56 Указ Президента ПМР от 3 августа 2012 г. №515 «Об Общественной палате Приднестровской Молдавской Республики», http://president.gospmr.ru/ru/news/ukaz-prezidenta-pmr-no515-ob-obshchestvennoy-palate-pridnestrovskoy-moldavskoy-respubliki (data dostępu: 15.09.2015 r.).

57 Указ Президента ПМР от 24 июня 2011 г.N 448 „, Об утверждении Положения о государственных наградах Приднестровской Молдавской Республики", http://zakon-pmr.com/DetailDoc.aspx?document=1 (data dostępu: 15.09.2015 r.).

58 Указ Президента ПМР от 14 марта 2011 г. №150 Об утверждении Положения о Координационном совете при Президенте Приднестровской Молдавской Республики по борьбе с преступностью и коррупцией, http://president.gospmr.ru/ru/news/ukaz-prezidenta-pmr-no150-ob-utverzhdenii-polozheniya-o-koordinacionnom-sovete-pri-prezidente (data dostępu: 15.09.2015 r.). 
prezydenckiego systemu rządów przybliżyło praktykę polityczną do postanowień ustawy zasadniczej. Uprawnienia przyznane przez Konstytucję Naddniestrza głowie państwa wypływają wprost z funkcji ustrojowych prezydenta. W Naddniestrzu stanowią one także samoistną podstawę do działania dla Prezydenta. Po przyjęciu Konstytucji z 1995 roku w pozycji ustrojowej prezydenta zachodziły pewne zmiany. Po pierwsze, dotyczyły one wymogów wobec kandydata na prezydenta. Wprowadzono cenzus obywatelstwa, a także ograniczenie liczby kadencji do dwóch. Najistotniejsza zmiana została dokonana pod koniec 2011 roku. W wyniku tychże zmian w 2012 roku dokonano wyodrębnienia najwyższego organu wykonawczego w postaci Rządu. Zachowano jednak znaczący wpływ Prezydenta tak na tworzenie Rządu, jak też jego bieżącą działalność. Spoglądając na inne uprawnienia Prezydenta można zauważyć, że posiada on uprawnienia należące do sfery wszystkich trzech władz, stąd można go uznawać za usytuowanego poza trójpodziałem władzy. Przyznany mu szczególny status, uprawnienia i odpowiedzialność pozwalają Prezydentowi odgrywać znaczącą rolę w życiu politycznym Naddniestrza.

\section{BIBLIOGRAFIA}

Конституция Приднестровской Молдавской Республики от 2 сентября 1991 г., http://zakon-pmr. com/DetailDoc.aspx?document=36582 [dostęp: 15.09.2015 r.].

Конституция Приднестровской Молдавской Республики от 24 декабря 1995 г., http://zakon-pmr. com/DetailDoc.aspx?document=36826 [dostęp: 15.09.2015 r.].

Конституционный закон от 2 октября 1996 г. „О выборах президента Приднестровской Молдавской Республики", http://zakon-pmr.com/DetailDoc.aspx?document=36407 [dostęp: 15.09.2015 r.].

Закон от 9 августа 2000 г. „Избирательный кодекс Приднестровской Молдавской Республики”, http://vspmr.org/file.xp?file=2245 [dostęp: 15.09.2015 r.].

Конституционный закон от 10 июля 2002 г. „Об особых правовых режимах”, http://zakon-pmr. com/DetailDoc.aspx?document=62611 [dostęp: 15.09.2015 r.].

Конституционный закон от 10 июля 2002 г. „О гражданстве Приднестровской Молдавской Республики”, http://vspmr.org/legislation/laws/zakonodateljnie-akti-pridnestrovskoy-moldavskoy-respubliki-v-sfere-konstitutsionnogo-stroya-osnov-pravoporyadka-a-takje-deyateljnosti-organov-gosudarstvennoy-vlasti-i-upravleniya/ konstitutsionniy-zakon-pridnestrovskoy-moldavskoy-respubliki-o-grajdanstve.html [dostęp: 15.09.2015 r.].

Закон от 24 октября 2001 г. „О регламенте Верховного совета Приднестровской Молдавской Республики”, http://vspmr.org/legislation/laws/zakonodateljnie-akti-pridnestrovskoy-moldavskoy-respubliki-v-sfere-konstitutsionnogo-stroya-osnov-pravoporyadka-a-takje-deyateljnosti-organov-gosudarstvennoy-vlasti-i-upravleniya/ zakon-pridnestrovskoy-moldavskoy-respubliki-o-reglamente-verhovnogo-soveta-pridnestrovskoy-moldavskoy-respubliki.html [dostęp: 15.09.2015 r.]. 
Конституционный закон от 9 ноября 2011 г „О Правительстве Приднестровской Молдавской Республики", http://gov-pmr.org/about [dostęp: 15.09.2015 r.].

Указ Президента ПМР от 4 июня 2015 г № 226 „Об утверждении Положения о Совете безопасности Приднестровской Молдавской Республики”, http://president.gospmr.ru/ru/ news/ukaz-prezidenta-pmr-no-226-ob-utverzhdenii-polozheniya-o-sovete-bezopasnosti-pridnestrovskoy [dostęp: 15.09.2015 r.].

Указ Президента ПМР от 25 июня 2013 г. №293 «О создании Высшего консультативного совета по науке и технике при Президенте Приднестровской Молдавской Республики», http:// president.gospmr.ru/ru/news/ukaz-prezidenta-pmr-no293-o-sozdanii-vysshego-konsultativnogo-soveta-po-nauke-i-tehnike-pri [dostęp: 15.09.2015 r.].

Указ Президента ПМР от 5 марта 2013 г. №86 «Об образовании при Президенте Приднестровской Молдавской Республики Общественного совета - Совета старейшин», http://president.gospmr.ru/ru/news/ukaz-prezidenta-pmr-no86-ob-obrazovanii-pri-prezidente-pridnestrovskoy -moldavskoy-respubliki [dostęp: 15.09.2015 r.].

Указ Президента ПМР от 3 августа 2012 г. №515 «Об Общественной палате Приднестровской Молдавской Республики», http://president.gospmr.ru/ru/news/ukaz-prezidenta-pmr-no515-ob -obshchestvennoy-palate-pridnestrovskoy-moldavskoy-respubliki [dostęp: 15.09.2015 r.].

Указ Президента Приднестровской Молдавской Республики от 5 марта 2012 года № 152 «Об образовании при Президенте Приднестровской Молдавской Республики Комиссии по вопросам помилования», http://president.gospmr.ru/en/news/ukaz-prezidenta-pmr-no152-ob -obrazovanii-pri-prezidente-pridnestrovskoy-moldavskoy-respubliki [dostęp: 15.09.2015 r.].

Указ Президента ПМР от 1 марта 2012 г. № 143 «Об утверждении Положения о Комиссии по вопросам гражданства при Президенте Приднестровской Молдавской Республики и ее состава», http://president.gospmr.ru/ru/news/ukaz-prezidenta-pmr-no143-ob-utverzhdenii-polozheniya-o-komissii-po-voprosam-grazhdanstva-pri [dostęp: 15.09.2015 r.].

Указ Президента ПМР от 20 февраля 2012 г. №115 «Об утверждении Положения об Администрации Президента Приднестровской Молдавской Республики», http://president. gospmr.ru/ru/news/ukaz-prezidenta-pmr-no115-ob-utverzhdenii-polozheniya-ob-administracii -prezidenta [dostęp: 15.09.2015 r.].

Указ Президента ПМР от 17 февраля 2012 г. №107 «О Консультативном Совете при Президенте Приднестровской Молдавской Республики по международным делам», http://president. gospmr.ru/ru/news/ukaz-prezidenta-pmr-no107-o-konsultativnom-sovete-pri-prezidente-pridnestrovskoy-moldavskoy [dostęp: 15.09.2015 r.].

Указ Президента ПМР от 24 июня 2011 г.N 448 „, Об утверждении Положения о государственных наградах Приднестровской Молдавской Республики", http://zakon-pmr.com/DetailDoc. aspx?document=1 [dostęp: 15.09.2015 r.].

Указ Президента ПМР от 14 марта 2011 г. №150 „Об утверждении Положения о Координационном совете при Президенте Приднестровской Молдавской Республики по борьбе с преступностью и коррупцией”, http://president.gospmr.ru/ru/news/ukaz-prezidenta -pmr-no150-ob-utverzhdenii-polozheniya-o-koordinacionnom-sovete-pri-prezidente [dostęp: 15.09.2015 r.].

Указ Президента ПМР от 16 февраля 2011 г. №105 „О порядке подготовки проектов правовых актов Президента Приднестровской Молдавской Республики и исполнительных органов государственной власти Приднестровской Молдавской Республики, а также 
государственной регистрации правовых актов”, http://president.gospmr.ru/ru/news/ukaz -prezidenta-pmr-no105-o-poryadke-podgotovki-proektov-pravovyh-aktov-prezidenta [dostęp: 15.09.2015 r.].

Указ Президента ПМР от 10 января 1997 года № 14 „О символах президентской власти Президента Приднестровской Молдавской Республики”, https://www.ulpmr.ru/pravo/ show/iWILLH017Trw2iOO70m29HaK1yMSg7kEyx+M= [dostęp: 15.09.2015 r.].

Алимов Боту Бабирович, „Опыт зарубежных стран в вопросах взаимоотношений президента и правительства”, Вопросы современной юриспруденции 2015, Н 47.

Дзыбова Саида Гиссовна, „Институт конституционно-правовой ответственности в современных правовых системах: сравнительно-правовой анализ”, Вестник Адыгейского государственного университета. Серия 1: Регионоведение: философия, история, социология, юриспруденция, политология, культурология 2008, Н 8.

Тхаркахо Марина Меджидовна, „Зарождение и развитие института президентской власти в зарубежных странах", Вестник Адыгейского государственного университета. Серия 1: Регионоведение: философия, история, социология, юриспруденция, политология, культурология 2007, Н 1. 
THE PRESIDENCY IN THE TRANSNISTRIAN MOLDAVIAN REPUBLIC

The subject of the article is the office of the president in the Transnistrian Moldavian Republic. Evolution of the presidential institution in Transnistria is very similar to that experienced in other countries of the former Soviet Union. From theoutset, however, in practice the constitutional president of Transnistria was the dominating factor. In 1995 the Constitution of Transnistria awarded the office special status, authority and responsibility for the state

Keywords: The president, presidential system, the executive authorities, Transnistria, the head of state, the state unrecognized

Słowa kluczowe: Prezydent, ustrój prezydencki, władza wykonawcza, Naddniestrze, głowa państwa, państwa nieuznawane 